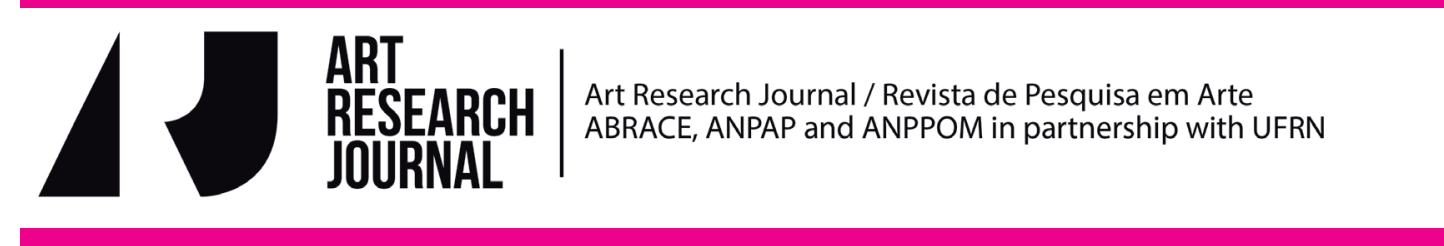

Relato da Presidente da ANPPOM para o ARJ 


\section{Relato da Presidente da ANPPOM para o ARJ}

Com base no acordo de Cooperação Técnica que celebraram a Fundação Universidade do Estado de Santa Catarina (UDESC), a Associação Brasileira de Pesquisa e Pós-graduação em Artes Cênicas ( ABRACE); a Associação Nacional de Pesquisadores em Artes Plásticas (ANPAP) e, a Associação Nacional de Pesquisa e Pós-Graduação em Música (ANPPOM), (mantenedoras do Art Research Journal - Revista de Pesquisa em Arte), a Presidente da ANPPOM, Prof. Dr. Sonia R. Albano de Lima, neste relato reitera o compromisso institucional assumido por esta associação, auxiliando a iniciativa naquilo que for necessário, seja na realização dos Encontros Anuais da ART Research Journal; na divulgação das decisões e deliberações realizadas no Forum Nacional de Editores de Periódicos da Área de Artes que passou a integrar o referido encontro a partir desse ano; na disseminação do periódico na comunidade acadêmica e nos PPGs da área; na indicação de pesquisadores para a realização de palestras e oficinas em seus encontros anuais; nas atividades de elaboração da Revista; na comunicação das decisões do Forum de Editores junto aos órgãos de fomento à pesquisa, com a intenção de que esse trabalho científico prolifere, já que tem como objetivo, divulgar uma produção artísticocientífica que agrega todas as linguagens artísticas e uma produção pautada nos princípios da interdisciplinaridade, ação investigatória que está sendo valorizado nos ordenamentos legais atuais ligados à educação, às ciências em geral e às artes. 
A Diretoria da ANPPOM também apoia os interesses desta iniciativa que consistem em: a- socializar os resultados da pesquisa em Artes para a comunidade artística, acadêmica e científica; b- divulgar o material de referência sobre pesquisa em artes e pesquisa artística para os cursos de graduação dos países de língua portuguesa; c- promover a produção brasileira junto à comunidade acadêmica internacional.

$\mathrm{Na}$ atualidade a interdisciplinaridade tem sido palco de inúmeras discussões científicas e educacionais, tanto no exterior como no Brasil. É uma forma alternativa, complementar e inovadora de produzir conhecimentos. Opera nas fronteiras disciplinares e na religação de saberes, tendo como finalidade, dar conta de fenômenos complexos de diferentes naturezas. Essa dimensão epistemológica propiciou-lhe um desdobramento diferenciado no campo do conhecimento, na educação e nas artes em geral. Ela estabelece pontes entre diferentes níveis de realidade, diferentes lógicas e diferentes formas de produção de conhecimento. 


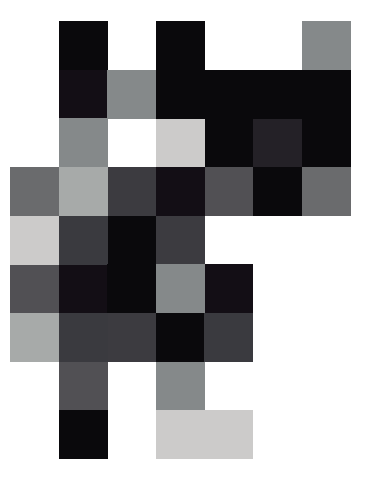

Com o processo de especialização do saber perpetuado pelo cientificismo, a interdisciplinaridade tem sido uma resposta benéfica para a excessiva compartimentalização do conhecimento. Hoje é importante gerar uma forma de conhecimento, seja ele científico ou artístico, capaz de enriquecer e ampliar a ação da ciência, da sociedade como um todo e da cultura. A interdisciplinaridade, seja nas artes, nas ciências ou na educação promove trocas teóricas e metodológicas significativas; gera novos conceitos; trabalha com graus crescentes de intersubjetividade entre os pesquisadores, visando atender a natureza múltipla dos fenômenos analisados com maior complexidade.

$\mathrm{Na}$ interdisciplinaridade uma interação circular vai se estabelecendo entre as ciências e as técnicas como espaços de surgimento de novos conceitos, desejos, paradigmas e de projetos dos indivíduos e das sociedades. Dessa forma, o exercício da competência científica tende a ser mais interativo e dialógico.

Com base nesses prognósticos, a linha editorial da ARJ que tem como meta a interligação das várias linguagens artísticas e a produção artístico-científica interdisciplinar traz para o futuro a incorporação na comunidade acadêmica nacional e internacional de um periódico propício para a produção de novos conhecimentos artísticos, incorporando a sua ação um sentido sociocultural e ético capaz de atuar beneficamente tanto na comunidade científica como na artística. 


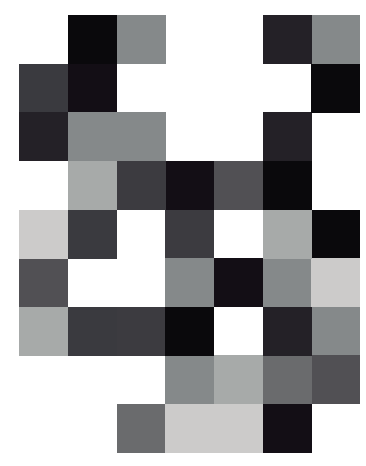

Revendo os volumes até agora publicados podemos vislumbrar uma produção artístico-científica que concilia prática e teoria, interliga as diversas linguagens artísticas e outras áreas de conhecimento, retrata a problemática que circunda a pesquisa em artes, referenda novas possibilidades de criação de textos e procedimentos de ação.

Embora ainda embrionária, a cada volume é notória a importância que o periódico confere à prática na elaboração de seus textos, o que se configura como uma especificidade que deve ser privilegiada.

Não bastasse, o Forum de Editores de Arte irá cumprir uma tarefa importantíssima para o reconhecimento das Artes como campo de pesquisa, discutindo temáticas relevantes, realizando oficinas, organizando GTs com o objetivo de difundir os resultados obtidos junto aos PPGs e nos órgãos de fomento à pesquisa.

Iniciativas como essa projetam para o futuro o reconhecimento das Artes como área de pesquisa, com especificidades próprias, distintas daquelas atribuídas as demais áreas de conhecimento.

Sonia Regina Albano de Lima

27 de setembro de 2016 